\title{
Winter dispersal and activity patterns of post- breeding black-legged kittiwakes Rissa tridactyla from Prince William Sound, Alaska
}

\author{
Aly McKnight ${ }^{1, *}$, David B. Irons ${ }^{1}$, Andrew J. Allyn ${ }^{2}$, Kelsey M. Sullivan ${ }^{3}$, \\ Robert M. Suryan ${ }^{4}$ \\ ${ }^{1}$ US Fish and Wildlife Service, 1011 East Tudor Rd., Anchorage, Alaska 99503, USA \\ ${ }^{2}$ Department of Natural Resource Conservation, University of Massachusetts-Amherst, Amherst, Massachusetts 01003, USA \\ ${ }^{3}$ Maine Department of Inland Fisheries and Wildlife, 650 State St., Bangor, Maine 04401, USA \\ ${ }^{4}$ Hatfield Marine Science Center, Oregon State University, Newport, Oregon 97365, USA
}

\begin{abstract}
As colony-specific wintering ecology of small and medium-sized seabirds is poorly understood, it has been generally assumed that winter conditions have the same effect on all individuals from any given colony. However, advances in global positioning technology now allow researchers to investigate movements of smaller seabirds. We tracked black-legged kittiwakes Rissa tridactyla using geolocator tags during the non-breeding season. Although kittiwakes as a group appear to be generalists with respect to overwintering strategy, our data indicate that individual birds are more specialized in their use of wintering habitat. Among birds tagged in the Gulf of Alaska, we identified 3 groups employing different wintering strategies: (1) resident birds that remain in the northern Gulf of Alaska; (2) coastal birds that remain within coastal and shelf waters but move as far south as California; and (3) pelagic birds that travel up to $1700 \mathrm{~km}$ offshore. Given that wintering conditions differ in widely spaced areas, the effects of winter on bird survival and body condition are likely not the same on all birds in a colony, as is often assumed. Activity data revealed that kittiwakes are almost entirely diurnal during the non-breeding season. We found significant differences in time allocation among wintering groups: birds that remained in the colony region spent less time loafing during the day and engaged in longer daytime flying and foraging bouts than birds that wintered farther from the colony. These differences suggest that wintering birds make trade-offs among travel distance, metabolic demands, and foraging quality.
\end{abstract}

KEY WORDS: Black-legged kittiwake $\cdot$ Rissa tridactyla $\cdot$ Geolocation $\cdot$ Activity sensor $\cdot$ Winter distribution $\cdot$ Winter activity $\cdot$ North Pacific

\section{INTRODUCTION}

Seabirds have long been recognized by many authors as potentially useful indicators of marine resources (e.g. Furness \& Nettleship 1991, Montevecchi 1993, Boyd \& Murray 2001). Availability and accessibility of food resources during the breeding season affect foraging success, which is in turn reflected in measurable aspects of breeding biology. Evidence suggests, however, that environmental conditions during the non-breeding season may have profound effects on breeding phenology (Frederiksen et al. 2004) and subsequent reproductive success (Chastel et al. 1995, Barbraud \& Chastel 1999, Daunt et al. 2005), as well as upon individual breeding status in that season (Chastel et al. 1995). Clearly, any attempt 
to use reproductive measurements to assess ecosystem health would benefit from a thorough understanding of the role that overwintering conditions may play in seabird reproductive success. This requirement necessitates identifying wintering ranges of such indicator populations, a task which has been problematic until the recent advent of miniaturized transmitters and position dataloggers. This technology has made it feasible to track seabird movements between post-breeding dispersal and subsequent arrival back at the colony in the following breeding season.

Geolocator dataloggers, which employ light geolocation (Wilson et al. 1992, Hill 1994), provide information that can be used to determine 2 geographic fixes per day for a tagged animal. Geolocators are not as accurate as satellite transmitters, but are much smaller and can easily be attached to leg bands of birds for year-round deployment. Because it is not a transmitter and requires no power or devices for transmitting, a geolocator tag can be small, light, and streamlined to minimize effects on a tagged animal's behavior (Phillips et al. 2004). It is, however, necessary to recapture tagged individuals in order to retrieve the data. To date, geolocation has been used to track movements of many animals, including marine mammals (Hill 1994), albatrosses (Shaffer et al. 2005), shearwaters (Gonzáles-Solís et al. 2007), petrels (Phillips et al. 2006), puffins (Harris et al. 2010), geese (Eichhorn et al. 2006), and even songbirds (Stutchbury et al. 2009).

Kittiwake breeding biology has been well studied at colonies throughout the northern hemisphere (e.g. Massaro et al. 2000, Cam et al. 2002, Ainley et al. 2003). Comparatively few studies, however, have investigated post-breeding dispersal, migration, and wintering location of birds from these colonies. Much of what we know about winter distribution of kittiwakes comes from at-sea surveys (Wynne-Edwards 1935, Rankin \& Duffey 1948, Gould et al. 1982, McKnight et al. 2008) and sparse data on sightings and recoveries of banded birds (Coulson 1966, D. B. Irons unpubl. data). These data generally indicate widespread winter dispersal throughout the North Atlantic and North Pacific, as well as coastal regions of Alaska, western Canada, and the western USA. With the exception of inferences made from band data, we know very little about how breeding colony location may affect winter distribution and activity.

In this study, we combined the use of geolocator and activity dataloggers to monitor winter movements and activity patterns of black-legged kittiwakes Rissa tridactyla (kittiwakes) from a large colony in south-central Alaska.

\section{MATERIALS AND METHODS}

\section{Deployment and retrieval of dataloggers}

We captured all birds in this study using nest snares, noose poles, or net guns. We captured and tagged 60 birds at a large (>10 000 kittiwakes) colony in Shoup Bay, in northeastern Prince William Sound (PWS), Alaska $\left(61^{\circ} 10^{\prime} \mathrm{N}, 146^{\circ} 35^{\prime} \mathrm{W}\right)$, and 5 birds at a large colony in Passage Canal, northwestern Prince William Sound $\left(60^{\circ} 47^{\prime} \mathrm{N}, 148^{\circ} 42^{\prime} \mathrm{W}\right)$. We deployed combined geolocator and immersion tags (Model Mk9, British Antarctic Survey) in 4 consecutive years (from 2006 to 2009). With one exception, recovered tags were retrieved during the breeding season following the deployment year. In August 2006, we tagged 16 birds (8 breeding pairs, 12 tags retrieved); in August 2007, 12 birds (6 breeding pairs, 10 tags retrieved); in August 2008, 12 birds (4 breeding pairs and 4 breeding singles, 6 tags retrieved); and in June and early July 2009, 25 nesting birds (no pairs, 15 tags retrieved). Five of the birds tagged in 2009 were captured at the northwestern PWS colony. One of the tags deployed in 2007 was retrieved in 2009 and therefore contained a full 2 seasons' worth of data.

During the first 3 years of the study (i.e. from 2006 to 2008), we attempted to maximize the probability of device retrieval by selecting mated, 'successful' pairs (i.e. those from which at least 1 chick had been fledged during the tagging year) in which at least 1 member was known to be between the ages of 7 and $13 \mathrm{yr}$, with an established history of breeding at the colony. We identified the sexes of most birds through morphometric assessment of head, bill, and wing length, a technique shown to be accurate in $\sim 90 \%$ of cases at the Middleton Island colony, $190 \mathrm{~km}$ south of our study colonies (Jodice et al. 2000). When both members of a pair were included (36 of the birds we initially tagged), sex determination likely approached $100 \%$ accuracy. Reproductive success was somewhat low for Pacific colonies, with $\sim 0.20$ chicks fledged per nest at the Shoup Bay colony during the 2006, 2007, and 2008 breeding seasons (D. B. Irons unpubl. data); in 2009 and 2010 the colony suffered complete failure. Therefore, the birds we captured in 2009 were all failed breeders both during the year before and the year after tag deployment. Because birds are much more difficult to capture when their nests are empty, we were unable to target birds of known-age for tag deployment in 2009.

We affixed each $2.5 \mathrm{~g}$ datalogger to a Darvic leg band using 2 ultraviolet-resistant cable ties. The combined mass of logger, leg band, and cable ties 
was $<5 \mathrm{~g}$, which represented $<1.5 \%$ of the body mass of even the smallest study bird. The tags sampled light levels once per minute, measured using an arbitrary, truncated scale developed by the British Antarctic Survey (Phillips et al. 2004). The maximum light level for each $10 \mathrm{~min}$ interval was recorded. Saltwater immersion ('wet' or 'dry') was assessed every $3 \mathrm{~s}$, and the total number of 'wet' readings was logged for each $10 \mathrm{~min}$ period. All retrieved geolocator tags remained functional throughout the study period.

\section{Analysis of light data}

We processed the data collected by each geolocator tag following the method described by Phillips et al. (2004). In overview, latitude can be estimated from day or night length, while longitude can be estimated from the time of local noon and midnight with respect to Greenwich Mean Time. We used BAStrack software (British Antarctic Survey) to decompress the downloaded light and activity data, as well as to correct for any clock drift experienced by the clock incorporated into the tag. We used the TransEdit application (British Antarctic Survey) to examine transitional light curves separating each light period ('day') from each dark period ('night'). We examined data on all dates between the initial deployment and the bird's return to the colony the following spring, where shading activity caused by nest-building rendered the light data unusable. We did not calculate positions when shading events rendered the transition time uncertain; the number of such transitions varied substantially among birds (from a few to dozens), as those remaining in mountainous coastal areas were far more likely to experience shading during sunrise and sunset. Based on an examination of the position data, we also chose to remove all dates within $20 \mathrm{~d}$ either side of the spring and autumnal equinoxes. Because day lengths are similar over all latitudes near the equinoxes, there was considerable error in latitude fixes obtained during this period. We used calibration data collected from dataloggers both on and off birds at a known location to determine an appropriate light threshold value (10 light units) and sun elevation value $\left(-4^{\circ}\right)$ to use in determining daily transition times. Because loggers record the peak light value over each 10 min period, we subtracted 10 min from each sunset transition time to compensate, as the peak light value would have occurred at the beginning of the 10 min interval during the transition from light to darkness. We also examined the data for nighttime light events that might indicate that the birds were associating with lighted fishing boats during the night (Gonzáles-Solís \& Croxall 2005).

Once we had calculated all possible transition times for each logger, we used the BirdTracker application (British Antarctic Survey) to calculate latitudes and longitudes at noon and midnight on each date with usable transition data. We removed positions requiring flight speeds of $>48 \mathrm{~km} \mathrm{~h}^{-1}$ sustained over a $24 \mathrm{~h}$ period ( $<30$ data points), as such high and sustained velocities seemed unlikely for a small gull (Spear \& Ainley 1997). We smoothed the remaining data twice before importing them into ArcGIS 9.3 (Environmental Systems Research Institute) and projecting them into an Alaska Albers Equal-Area projection. We discovered that, for kittiwakes in coastal waters, light interference from coastal mountains at sunrise and sunset tended to displace positions substantially to the south (between the spring and fall equinox) or to the north (between the fall and the spring equinox). Because saltwater immersion data indicated that none of the study birds spent significant time inland, we removed any calculated positions that lay inland more than $300 \mathrm{~km}$ from the coastline, the margin of error for geolocation fixes (Phillips et al. 2004). Again, the number of points removed varied by bird; birds that spent time in mountainous coastal areas had far more erroneous land records than did birds in open water. We assumed that all remaining inland points resulted from northward error in the winter months, driven by artificially shortened day length in mountainous coastal regions. Overall, data filtering of shaded transitions, assumption of unrealistic flight speeds, and erroneous inland locations removed a median of $32 \%$ of positions for each bird (range 8 to $74 \%$ ).

To examine overwintering location, we selected data between November and February each season, a period during which the colony is vacant, and generated kernel density distributions (cell size $=50 \mathrm{~km}$, search radius $=200 \mathrm{~km}$ ) for each year using the ArcGIS 9.3 Spatial Analyst Density tool. Although locations were not serially independent, such independence is not an assumption of kernel density analysis (De Solla et al. 1999). As the data suggested that birds might be employing different overwintering dispersal strategies, we also generated kernel density contour maps for resident, coastal, and pelagic birds from all years using the same method. Birds were assigned to a dispersal group if they spent 3 or more of the months between November and February in that region. 
To investigate relationships between bird positions and oceanographic variables, we examined position data with respect to satellite-derived data for several habitat variables. We first overlaid the $0.2 \mathrm{mg} \mathrm{m}^{-3}$ chl a isopleth on our kernel density distributions, identified using the ArcGIS 9.3 Spatial Analyst Surface Tool from winter seasonal chlorophyll data collected by the MODIS Aqua sensor (Feldman \& McClain 2010). This isopleth generally denotes the seasonal average of the boundary of the Transition Zone Chlorophyll Front (TZCF) separating the lowchlorophyll subtropical gyres and the high-chlorophyll subarctic gyres (Polovina et al. 2001). We also examined both the grouped and individual positions with respect to remotely sensed nighttime sea surface temperature (Feldman \& McClain 2010), and monthly mean sea level anomaly altimetry data obtained from http://www.aviso.oceanobs.com, distributed by Aviso with support from the Centre National d'Études Spatiales, France.

We determined the sexes of most tagged birds. The 2006-2007 sample included 7 males and 8 females; the 2007-2008 sample, 5 males and 5 females; the 2008-2009 sample, 1 male, 4 females, and 1 bird of unknown sex; and the 2009-2010 sample, 7 males, 6 females, and 2 birds of unknown sex. To investigate the effects of sex on offshore dispersal, we calculated the mean distance from shore for each bird of known sex in autumn (from October 12 to December 19) and winter (from December 20 to February 28) of each year; dates prior to October 12 and after February 28 fall into the equinox periods for which the geolocator data were unreliable. We compared the mean distance to shore for males and females in autumn and winter in 2006-2007, 2007-2008, and 2009-2010 using a 1-way analysis of variance (ANOVA). We omitted 2008-2009 from this analysis because only one of the 6 birds was identified as a male.

\section{Analysis of activity data}

We identified 3 types of behavior from the saltwater immersion data: (1) 'Loafing,' which occurred when the logger was submerged for at least one 10 min period, indicating that the bird was sitting on the water; (2) 'Flying/roosting,' which occurred when the logger was entirely dry for at least one $10 \mathrm{~min}$ period, as would occur when a bird was flying or roosting on land or on floating debris; and (3) 'Probable foraging,' which occurred when the logger recorded intermittent wet and dry states for at least one $10 \mathrm{~min}$ period. Kittiwakes forage by making short shallow dives into water from the air, or by floating on the surface and seizing prey (Burger 1988). As aerial plunge diving behavior involves actively transitioning from air to water, this behavior was logged as intermittent wet-dry activity (Burtt 1974, Burger 1988). Feeding from the surface may also be recorded as intermittent wet-dry, as the activity often involves active splashing (A. McKnight, D. B. Irons, A. J. Allyn pers. obs.). Although intermittent wet-dry records likely also included non-foraging behaviors (e.g. preening, intensive scratching, or stretching), we believe that such records are a reasonable indication of foraging activity when compared among groups. Because immersion data were assessed over 10 min intervals, we chose to eliminate probable foraging ('foraging' hereinafter) records that occurred during only one 10 min period between a loafing period and a flying/roosting period (or vice versa). Such records most likely indicated that the bird made the transition from loafing to flying/roosting (or vice versa) during that transitional $10 \mathrm{~min}$ period, and was not foraging. Also, to account for incidental behaviors, such as scratching and stretching, that might cause intermittent dry readings while the bird was otherwise loafing on the water, we classified any activity record of 195 or greater (out of a maximum value of 200 for any 10 min period) as 'loafing'.

We calculated the duration in minutes (multiples of 10) for each behavior on every day of logger deployment for each bird. Using the light data recorded at simultaneous intervals, we grouped behaviors into 'night' (recorded light level $=0$ ) and 'day' (maximum recorded light level $=64$, achieved $<30$ minutes after sunrise even on days with heavy cloud cover) for each day of deployment. We ignored activities that occurred during transition light levels. We calculated the average number of min per day that each bird spent in loafing, flying/roosting, and foraging activities between November 1 and February 28 (February 29 in 2008). We also calculated the average duration of loafing bouts, flying/roosting bouts, and foraging bouts for each bird during the same time period.

To examine yearly differences in winter behavior, we compared the average number of min per day spent in loafing, flying/roosting, and foraging, as well as the average duration of bouts of each activity type, between November 1 and February 28 (February 29 in 2008) among the study years. To make the comparisons, we first performed an ANOVA test $(\alpha=$ 0.05 ) to determine whether a significant yearly difference existed and, when warranted, a Tukey-Kramer test to identify which pairs of values were significantly different $(\alpha=0.05)$. Because we suspected that 
some yearly differences resulted from differing predominant wintering locations among years, we also compared behaviors among non-dispersers, coastal dispersers, and offshore dispersers (pooled years).

\section{RESULTS}

\section{Spatial analysis}

We generated kernel density maps for 2006-2007 $(\mathrm{n}=12), 2007-2008(\mathrm{n}=10), 2008-2009(\mathrm{n}=6)$, and 2009-2010 ( $\mathrm{n}=15)$ kittiwake distributions from November through February. The nearshore region of south-central Alaska was included in the core range for all years. Although some birds wintered in the open ocean beyond the shelf break, many birds remained in coastal and shelf waters throughout the winter season (Fig. 1). The general range in 2006-2007 appears to be greater than in the other years, with the core area including a region $1300 \mathrm{~km}$ offshore. This pelagic region was also important, although less so, for the 2008-2009 birds.
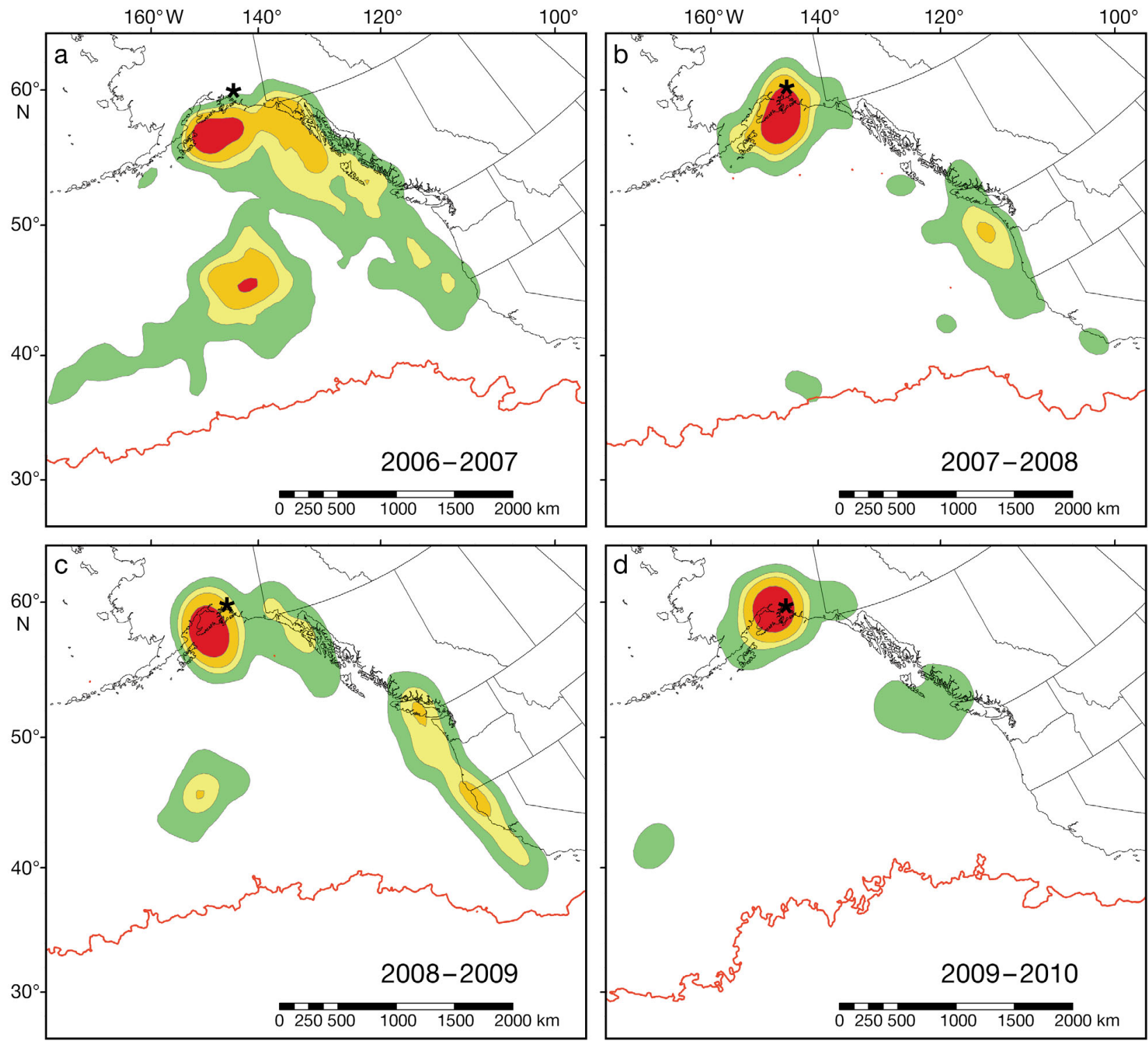

Fig. 1. Rissa tridactyla. Kernel density maps for tagged kittiwakes, November to February of (a) 2006-2007, (b) 2007-2008, (c) 2008-2009, (d) 2009-2010. Red (core range): 50\%; orange: $75 \%$; yellow: $85 \%$; green (general range): $95 \%$. Red line: 0.2 mg $\mathrm{m}^{-3} \mathrm{chl}$ a isopleth, representing the boundary of the Transition Zone Chlorophyll Front (TZCF). Asterisk = location of Shoup 
Both 2006-2007 and 2009-2010 were El Niño years. Kernel density distributions were very different in these $2 \mathrm{yr}$, with some 2006-2007 birds traveling far offshore, while most 2009-2010 birds did not disperse far from the breeding region. The general range of birds in 2009-2010 did include, however, a zone off the coast of southern British Columbia where 5 birds spent time in the fall. This zone overlapped with a temporary meander in the TZCF, visible in the seasonal mean data for autumn 2009 (Fig. 2).

The data showed that birds employed individual wintering strategies, with some birds remaining confined to coastal waters and others traveling offshore. Most individual tracks in all years could be grouped into 1 of 3 categories based on the predominant pattern: (1) 'resident birds' showed no dispersal from the general colony region ( $\mathrm{N}=16)$; (2) 'coastal birds' dispersed to coastal and shelf waters in Alaska, British Columbia, and the western USA ( $N=7)$; and (3) 'pelagic birds' dispersed to offshore waters well beyond the edge of the continental shelf $(\mathrm{N}=16)$. The remaining 4 birds exhibited combinations of these strategies and were not included in the dispersal region analysis. One of the 4 split his time evenly between the pelagic (from November to December) and the resident strategies (January to February), another displayed the reverse pattern (resident from November to December and pelagic from January to February), and the remaining 2 birds' tracks were observed through all 3 regions. We overlaid the 50 and $75 \%$ contours of the kernel density distributions

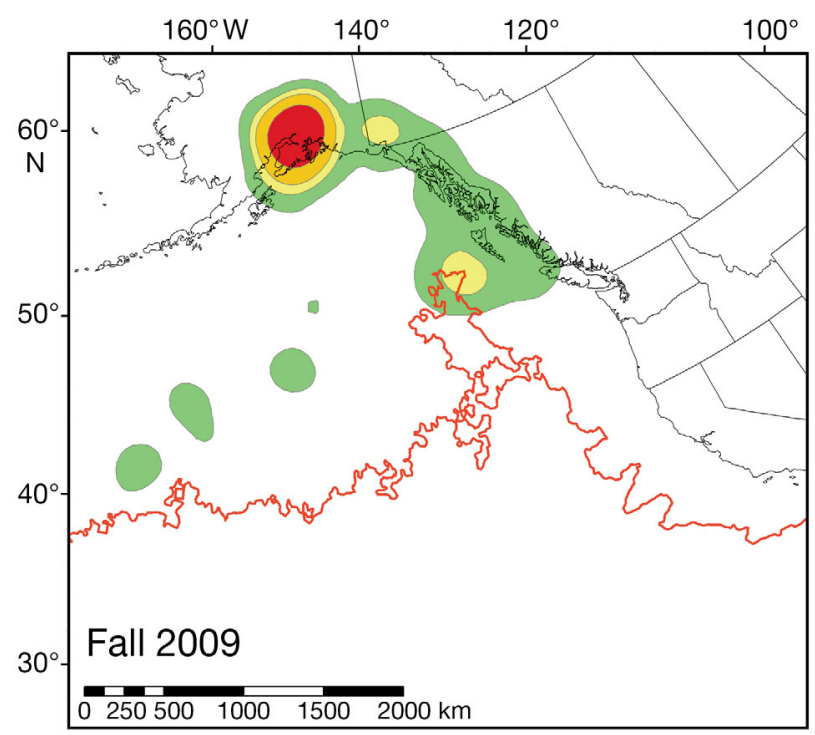

Fig. 2. Rissa tridactyla. Kernel density map for tagged kittiwakes between October 11 and December 19, 2009. See Fig. 1 legend for explanation of colors and red line for each group (pooled years) on a single map to illustrate the segregation of winter ranges among the 3 groups (Fig. 3).

Upon examination of bird location data, several patterns became evident with respect to environmental data. First, tagged birds virtually always remained north of the TZCF. Oceanographic conditions near the TZCF are very dynamic, with prominent cyclonic and anti-cyclonic eddies. It is possible that some birds exhibiting a pelagic wintering strategy may have taken advantage of potential prey concentrations or aggregations associated with these offshore hydrographic features (e.g. Fig. 4). Also, seasonal nighttime sea surface temperature data showed that the waters of Prince William Sound were roughly $1^{\circ} \mathrm{C}$ warmer in 2009-2010, the year in which most birds were non-dispersers, in comparison to the other 3 yr.

We found no significant difference at the $\alpha=0.05$ level in offshore dispersal between males and females in autumn and winter of the $3 \mathrm{yr}$ with comparable data, although the comparison between males and females in autumn 2006 was significant at the $\alpha=0.1$ level (Table 1). Tracks of mated pairs ( $\mathrm{N}=4$ pairs in 2006-2007, $\mathrm{N}=4$ pairs in 2007-2008, $\mathrm{N}=1$ pair in 2008-2009) revealed that the breeding pairs in our study did not remain together through the winter.

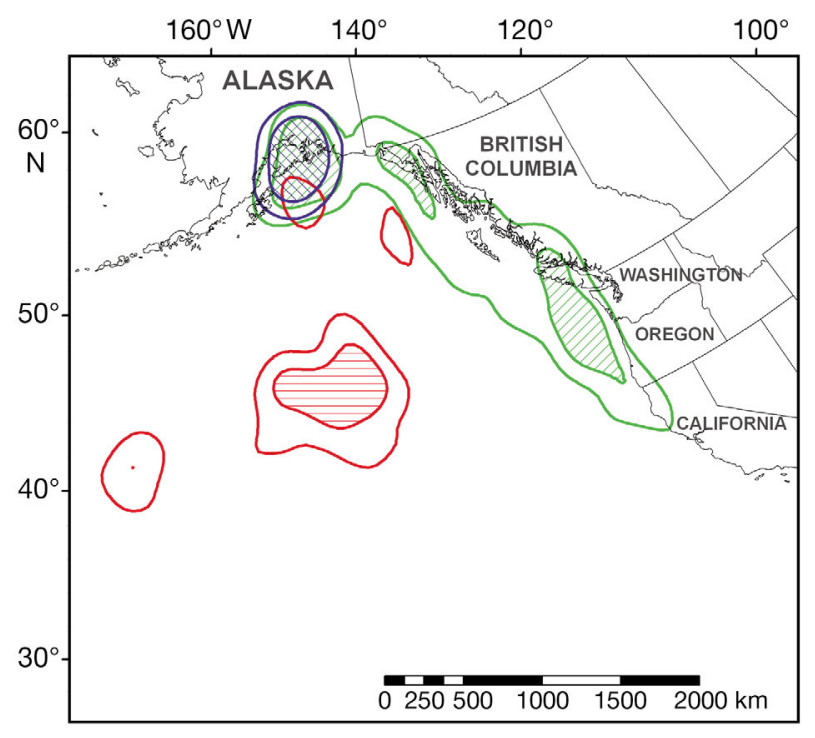

Fig. 3. Rissa tridactyla. Kernel density map of birds exhibiting 3 different wintering strategies. Blue: residents $(\mathrm{N}=16$, pooled years); green: coastal birds $(\mathrm{N}=7)$; red: pelagic birds $(\mathrm{N}=16)$. Empty polygons: $75 \%$ density regions; hatched polygons: $50 \%$ (core) density regions. Several coastal birds spent some time in the colony region before or after dispersing to other coastal regions, causing the colony region to be included in the core range of coastal birds 


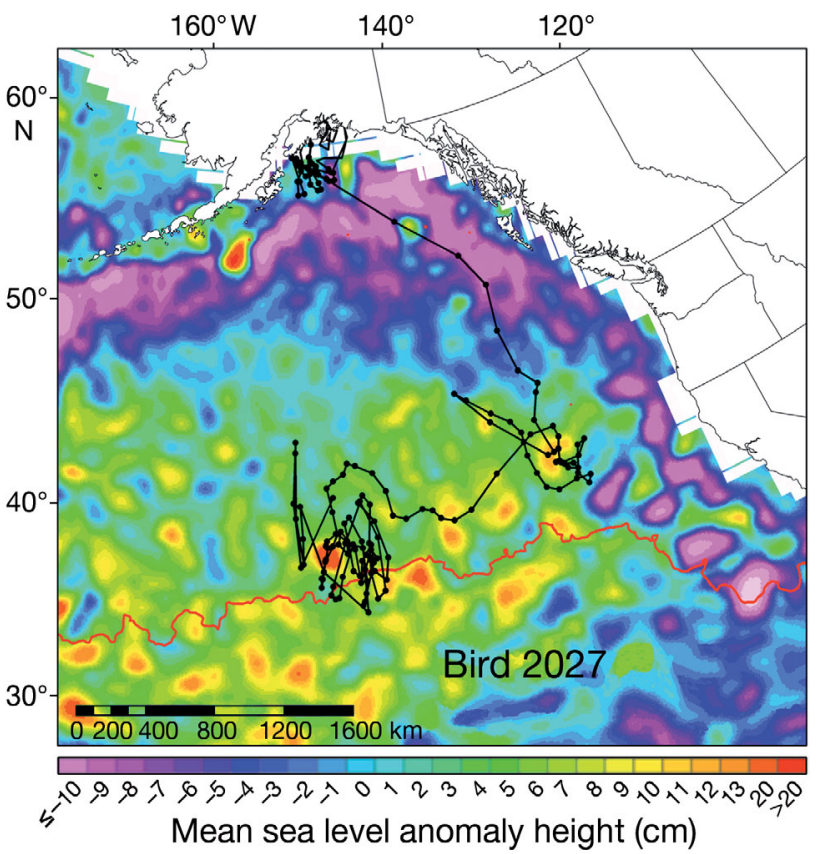

Fig. 4. Rissa tridactyla. Oceanic eddies near the Transition Zone Chlorophyll Front (TZCF) as possible foraging habitat for kittiwakes such as Bird 2027, December 2007-February 2008. Colors denote mean sea level height anomalies for February 2008. High positive values may indicate persistent warm anticyclonic eddies. Red line: winter $0.2 \mathrm{mg} \mathrm{m}^{-3} \mathrm{chl} \mathrm{a}$ isopleth, indicating average winter position of TZCF

Table 1. Rissa tridactyla. ANOVA comparison of average dispersal distance from shore by season between males and females in 2006-2007, 2007-2008, and 2009-2010. No comparison was significant at the $\alpha=0.05$ level

\begin{tabular}{|lcccc|}
\hline Season & $\begin{array}{c}\text { Average distance from } \\
\text { shore }(\mathrm{km})\end{array}$ & $F$ & $\mathrm{p}$ \\
& Males (N) & Females (N) & & \\
\hline 2006-2007 & & & & \\
Autumn & $548(7)$ & $180(5)$ & 3.93 & 0.08 \\
Winter & $678(7)$ & $266(5)$ & 2.06 & 0.18 \\
2007-2008 & & & & \\
Autumn & $44(5)$ & $72(5)$ & 1.46 & 0.26 \\
Winter & $355(5)$ & $161(5)$ & 0.35 & 0.57 \\
2009-2010 & & & & \\
Autumn & $95(7)$ & $13(6)$ & 2.27 & 0.16 \\
Winter & $95(7)$ & $10(6)$ & 2.41 & 0.15 \\
\hline
\end{tabular}

\section{Activity analysis}

In general, all birds spent most of the night loafing, while spending substantial time engaged in each of the 3 discernible behaviors during daylight hours (Figs. $5 \& 6$ ). We found no record of nighttime light, suggesting little or no nocturnal association with
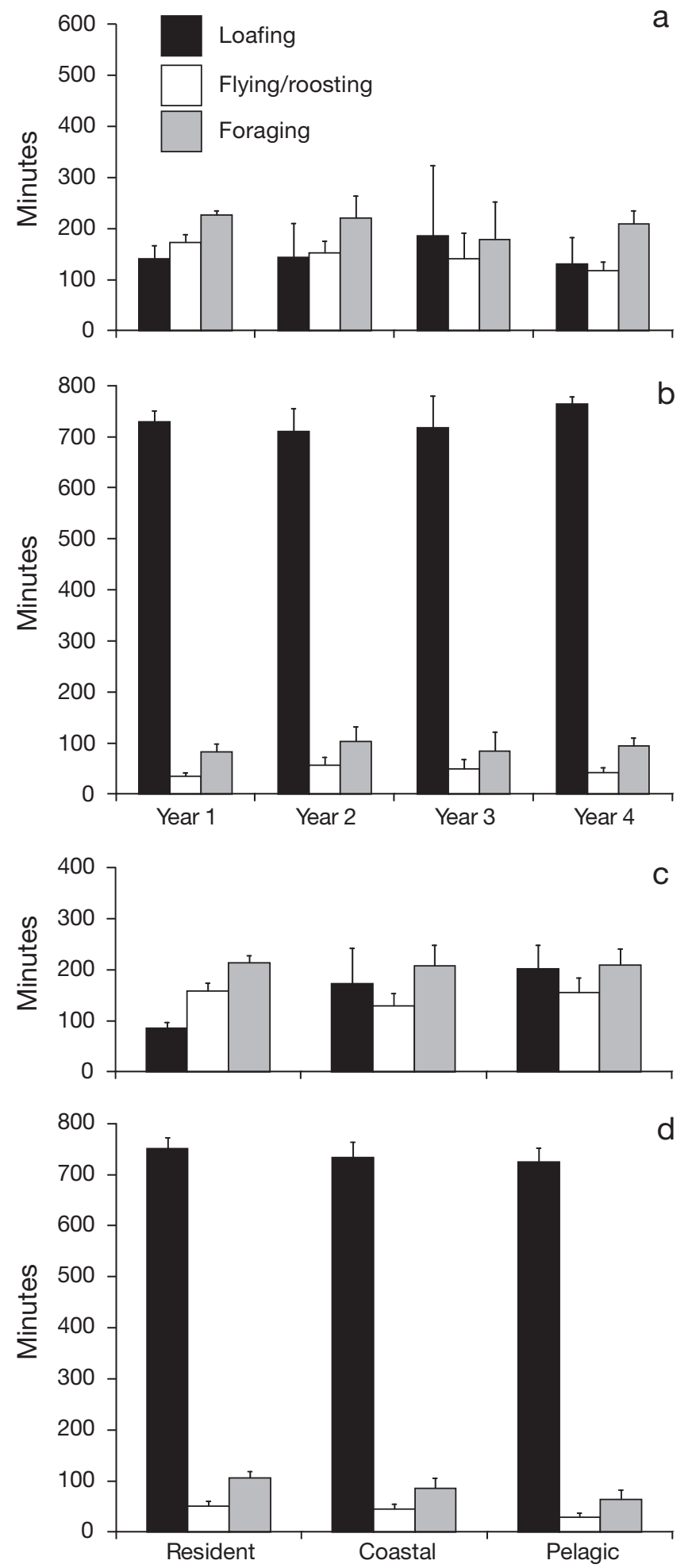

Fig. 5. Rissa tridactyla. Average (+ SE) number min per day spent in 3 activity types. (a) Daily time spent in each activity type among years, (b) nightly time spent in each activity type among years, (c) daily time spent in each activity type among wintering strategies (pooled years), and (d) nightly time spent in each activity type among wintering strategies (pooled years) 

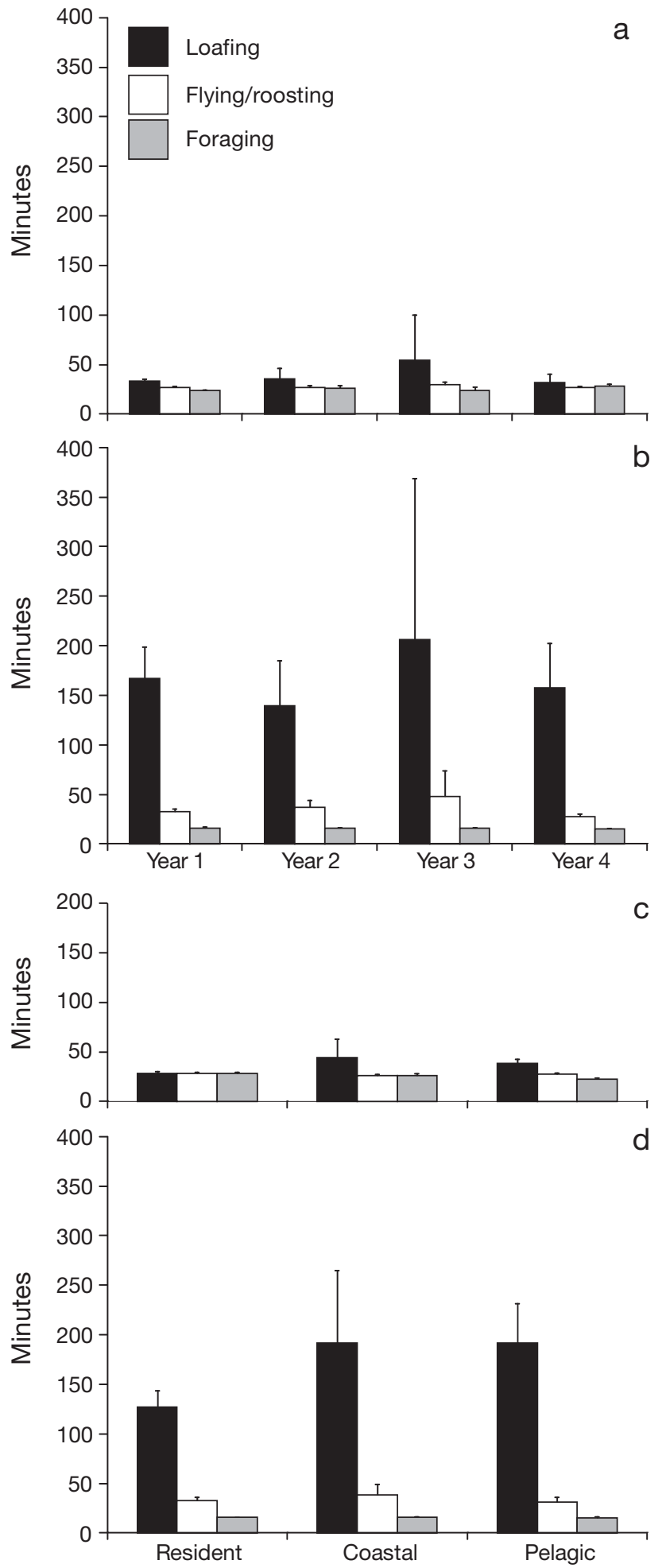

Fig. 6. Rissa tridactyla. Average ( $\pm \mathrm{SE}$ ) bout length in min for 3 activity types. (a) Daily time spent in each activity type among years, (b) nightly time spent in each activity type among years, (c) daily time spent in each activity type among wintering strategies (pooled years), and (d) nightly time spent in each activity type among wintering strategies (pooled years) lighted vessels. Some behavior patterns varied significantly among years. During the day in 2006-2007, tagged birds spent more time flying/roosting and less time foraging than in 2009-2010. Birds in 2008-2009 spent a greater amount of time flying/roosting at night than did birds in 2009-2010 (Tables 2 \& 3). Behavior patterns varied by wintering location as well. Residents spent significantly less time loafing during the day than either coastal or pelagic birds, and spent more time foraging at night than pelagic birds. In addition, residents had significantly longer daytime flying/roosting bouts than coastal birds. Residents also engaged in longer daytime foraging bouts than did pelagic birds (Tables $2 \& 3$ ).

\section{DISCUSSION}

This is the first study to provide detailed data on post-breeding season dispersal and activity patterns of black-legged kittiwakes from a known breeding site in the Gulf of Alaska. Kittiwakes proved to be an ideal subject for logger-based biological data collection, as they are relatively easy to capture and exhibit a high degree of nest-site fidelity between years, making recapture and recovery of loggers fairly simple. We were able to identify several important winter-use regions for kittiwakes from Prince William Sound. The coastal habitats of south-central and southeast Alaska, as well as coastal British Columbia, particularly Vancouver Island, were frequented by many birds. In addition, an offshore area roughly $1500 \mathrm{~km}$ south of Prince William Sound was used heavily by birds in December 2006 and to a lesser extent in the winter of 2008 to 2009. Post-breeding dispersal patterns seemed to differ substantially between years, particularly between 2006-2007 and 2009-2010. More birds dispersed far offshore in 2006-2007, whereas most birds remained in the region of the breeding colony in 2009-2010. We found no relationships between sex and offshore dispersal, although our sample size was likely too small to detect such differences.

Numerous studies have revealed associations between apex predators and sea surface temperature (e.g. O'Hara et al. 2006, Kappes et al. 2010), upwelling zones (e.g. Phillips et al. 2005, Gonzáles-Solís et al. 2007), shelf breaks (e.g. Schneider 1982, Kinder et al. 1983), oceanic fronts (e.g. Polovina et al. 2001), and eddies (e.g. Weimerskirch et al. 2004). Unfortunately, limitations in satellite surveillance of the visible spectrum during the winter months prevented a direct analysis of bird position relative to production 
Table 2. Rissa tridactyla. Comparisons of average min per day spent in each of 3 activity categories by year and wintering strategies. For wintering strategies, results data are pooled across all years. Average values and $95 \%$ CI are reported by group when differences are significant; otherwise they are reported for all birds in the results by year. ANOVA F-ratio values and corresponding p-values are shown for significant tests, as well as p-values for subsequent significant Tukey-Kramer results. ${ }^{*}$ denotes groups showing significant differences $(\mathrm{p}<0.05)$

\begin{tabular}{|c|c|c|c|c|}
\hline Comparison & Group & $\mathrm{N}$ & Average $\pm 95 \% \mathrm{CI}\left(\mathrm{min} \mathrm{d}^{-1}\right)$ & Test result \\
\hline \multicolumn{5}{|l|}{ AMONG YEARS $^{a}$} \\
\hline \multicolumn{5}{|l|}{ Day } \\
\hline Loafing & All years & 43 & $144 \pm 31$ & No difference among years \\
\hline \multirow[t]{4}{*}{ Flying/roosting } & Year $1^{*}$ & 12 & $173 \pm 16$ & $F=4.87, \mathrm{p}=0.006$ \\
\hline & Year 2 & 10 & $153 \pm 23$ & Year $1>$ Year $4, p=0.003$ \\
\hline & Year 3 & 6 & $140 \pm 52$ & \\
\hline & Year $4^{*}$ & 15 & $118 \pm 17$ & \\
\hline Foraging & All years & 43 & $212 \pm 17$ & No difference among years \\
\hline \multicolumn{5}{|l|}{ Night } \\
\hline Loafing & All years & 43 & $735 \pm 11$ & No difference among years \\
\hline Flying/roosting & All years & 43 & $44 \pm 6$ & No difference among years \\
\hline Foraging & All years & 43 & $92 \pm 11$ & No difference among years \\
\hline \multicolumn{5}{|c|}{ AMONG WINTERING STRATEGIES } \\
\hline \multicolumn{5}{|c|}{ Day } \\
\hline \multirow[t]{3}{*}{ Loafing } & Resident birds* & 16 & $86 \pm 11$ & $F=4.78, \mathrm{p}=0.014$ \\
\hline & Coastal birds* & 7 & $172 \pm 71$ & Coastal $>$ Resident, $\mathrm{p}=0.043$ \\
\hline & Pelagic birds* & 16 & $202 \pm 47$ & Pelagic $>$ Resident, $\mathrm{p}=0.032$ \\
\hline Flying/roosting & All strategies & 39 & $145 \pm 14$ & No difference among groups \\
\hline Foraging & All strategies & 39 & $211 \pm 18$ & No difference among groups \\
\hline \multicolumn{5}{|l|}{ Night } \\
\hline Loafing & All strategies & 39 & $739 \pm 16$ & No difference among groups \\
\hline Flying/roosting & All strategies & 39 & $44 \pm 7$ & No difference among groups \\
\hline \multirow[t]{3}{*}{ Foraging } & Resident birds* & 16 & $106 \pm 13$ & $F=4.17, \mathrm{p}=0.024$ \\
\hline & Coastal birds & 7 & $86 \pm 20$ & Resident $>$ Pelagic, $\mathrm{p}=0.021$ \\
\hline & Pelagic birds* & 16 & $64 \pm 19$ & \\
\hline
\end{tabular}

in the Gulf of Alaska region. Examination of individual tracks indicated that some tagged birds may have associated with one or more of these physical features, but there appears to be no single factor determining the overall distribution of our tagged birds.

Climate cycles such as the El Niño/Southern Oscillation may play a role in the dispersal choices of wintering seabirds. El Niño conditions can greatly reduce summertime coastal upwelling, causing nutrient depletion in waters along the northwest coast that can persist throughout the winter, while simultaneously favoring open ocean production (Whitney \& Welch 2002). In contrast, La Niña conditions can increase summer upwelling and raise nutrient levels substantially through the winter months (Whitney \& Welch 2002). El Niño conditions can also affect the shape of the TZCF, causing the boundary to meander substantially in comparison to La Niña years, which may enrich the foraging habitat for apex predators along the front (Polovina et al. 2001). In addition, El Niño events may correspond to periods of increased eddy activity, although this relationship is not always straightforward (Henson \& Thomas 2008).

Two of our study seasons, 2006-2007 and 20092010, took place during El Niño years, with the 20092010 El Niño being the stronger of the two (Lee \& McPhaden 2010). Both the intervening seasons occurred during La Niña conditions. The increased offshore dispersal we observed in 2006-2007 may have been a response to El Niño conditions in that year, which may have favored open ocean production over coastal production. However, there was no comparable response during the second, stronger, El Niño event in 2009-2010.

We found that individual kittiwakes from the same colony practice different wintering strategies. We were able to identify 3 wintering strategies employed by birds tagged in the Gulf of Alaska: birds that can be classified as resident, coastal, or pelagic. The res- 
Table 3. Rissa tridactyla. Comparisons of average bout length for the 3 activity categories by year and wintering strategies. See Table 2 legend for details

\begin{tabular}{|c|c|c|c|c|}
\hline Comparison & Group & $\mathrm{N}$ & Average $\pm 95 \%$ CI $\left(\min\right.$ bout $\left.^{-1}\right)$ & Test result \\
\hline \multicolumn{5}{|l|}{ AMONG YEARS $^{\mathrm{a}}$} \\
\hline Loafing bout & All years & 43 & $36 \pm 7$ & No difference among years \\
\hline Flying/roosting bout & All years & 43 & $27 \pm 1$ & No difference among years \\
\hline Foraging bout & $\begin{array}{l}\text { Year } 1^{*} \\
\text { Year } 2 \\
\text { Year } 3 \\
\text { Year } 4^{*}\end{array}$ & $\begin{array}{c}12 \\
10 \\
6 \\
15\end{array}$ & $\begin{array}{l}24 \pm 1 \\
26 \pm 3 \\
24 \pm 4 \\
28 \pm 2\end{array}$ & $\begin{array}{l}F=3.41, \mathrm{p}=0.027 \\
\text { Year } 4>\text { Year } 1, \mathrm{p}=0.036\end{array}$ \\
\hline \multicolumn{5}{|l|}{ Night } \\
\hline Flying/roosting bout & $\begin{array}{l}\text { Year } 1 \\
\text { Year } 2 \\
\text { Year } 3^{*} \\
\text { Year } 4^{*}\end{array}$ & $\begin{array}{c}12 \\
10 \\
6 \\
15\end{array}$ & $\begin{array}{l}32 \pm 3 \\
37 \pm 7 \\
48 \pm 26 \\
28 \pm 3\end{array}$ & $\begin{array}{l}F=3.33, \mathrm{p}=0.029 \\
\text { Year } 3>\text { Year } 4, \mathrm{p}=0.021\end{array}$ \\
\hline Foraging bout & All years & 43 & $16 \pm 0.2$ & No difference among years \\
\hline \multicolumn{5}{|c|}{$\begin{array}{l}\text { AMONG WINTERING STRATEGIES } \\
\text { Day }\end{array}$} \\
\hline Loafing bout & All strategies & 39 & $37 \pm 8$ & No difference among groups \\
\hline Flying/roosting bout & $\begin{array}{l}\text { Resident birds* } \\
\text { Coastal birds* } \\
\text { Pelagic birds }\end{array}$ & $\begin{array}{c}16 \\
7 \\
16\end{array}$ & $\begin{array}{l}29 \pm 1 \\
26 \pm 2 \\
27 \pm 2\end{array}$ & $\begin{array}{l}F=3.73, p=0.034 \\
\text { Resident }>\text { Coastal, } p=0.026\end{array}$ \\
\hline Foraging bout & $\begin{array}{l}\text { Resident birds* } \\
\text { Coastal birds } \\
\text { Pelagic birds }\end{array}$ & $\begin{array}{c}16 \\
7 \\
16\end{array}$ & $\begin{array}{l}28 \pm 2 \\
26 \pm 2 \\
22 \pm 1\end{array}$ & $\begin{array}{l}F=4.77, \mathrm{p}=0.015 \\
\text { Resident }>\text { Pelagic } \mathrm{p}=0.011\end{array}$ \\
\hline \multicolumn{5}{|l|}{ Night } \\
\hline Loafing bout & All strategies & 39 & $165 \pm 33$ & No difference among groups \\
\hline Flying/roosting bout & All strategies & 39 & $35 \pm 5$ & No difference among groups \\
\hline Foraging bout & All strategies & 39 & $16 \pm 0.4$ & No difference among groups \\
\hline
\end{tabular}

ident birds stayed in the northern Gulf of Alaska, not flying farther from their breeding colony than is possible to fly in one day, moving along the shelf to the shelf break and beyond. The coastal birds moved as far south as California $(\sim 3000 \mathrm{~km})$, also remaining within coastal and shelf waters. The pelagic birds, in contrast, traveled up to $1700 \mathrm{~km}$ offshore. We were surprised to see that some birds never left the region, although kittiwakes have been recorded overwintering around Kodiak Island in the northern Gulf in recent years (R. Macintosh pers. comm.). Perhaps as the oceans are warming, the northern Gulf of Alaska is becoming more productive during winter than in the past. The 2009-2010 winter was the warmest of the 4 years during which we tracked birds, and it was also the year that most birds remained resident in the northern Gulf.

Our data differ markedly from data collected in the Bering Sea. A recent study on kittiwakes in the Pri- blilof Islands showed that almost all birds wintered far offshore, with none remaining around the Pribilofs and only a few staying close to shore along the Aleutian Islands during the winters of 2008-2009 and 2009-2010 (R.Orben pers. comm.). Reasons for differences in wintering strategies between the Pribilof birds and the Prince William Sound birds are unknown, although it is interesting to note that birds from Prince William Sound often forage along shore in summer (Irons 1998) and birds in the Pribilofs generally forage far from shore during summer (R. Paredes pers. comm.). The idea that individual birds that forage coastally in the summer also forage coastally in the winter, and birds that forage offshore in summer also do so in winter can be tested in future work. Finding such specialization would be important, as it would provide more evidence that learning to forage at sea where prey are under water and cannot be detected from a distance is a difficult and compli- 
cated task for a flying seabird. Once birds learn a general strategy, they may try to use the same foraging strategy during summer and winter.

Our results, along with results from similar studies in the Bering Sea (R. Orben pers. comm.) and the Atlantic (Bogdanova et al. 2011), indicate that winter dispersal of kittiwakes is a complex phenomenon. Birds from an eastern Atlantic colony appeared to disperse based upon recent breeding success, with failed breeders traveling as far as the western Atlantic for the winter months and successful breeders remaining closer to the colony site (Bogdanova et al. 2011). This is likely not the case for the birds in Prince William Sound. Although we were not able to analyze all of our data in relation to breeding success, the summer of 2009 gives us an example of a breeding season in which all of our birds failed to breed, yet during the winter of 2009 to 2010 most birds remained resident in the northern Gulf of Alaska. If there was an effect of breeding success, it would have been the opposite of the effect found in the Atlantic.

The activity data provided an unprecedented view of the daily activity patterns of tagged kittiwakes throughout the non-breeding season. All individuals exhibited predominantly diurnal behavior patterns, spending most of the nighttime hours floating on the surface of the water. This activity pattern is comparable to that reported by Daunt et al. (2002) for kittiwakes in the North Sea during the breeding season.

Humphreys et al. (2007) found that resting on the water for prolonged periods may be energetically costly for kittiwakes when water temperatures are low. The increased costs associated with the long nights and cold waters found in northern latitudes would seemingly provide an incentive for birds to disperse southward toward warmer water and shorter nights during the winter season. In this study, resident birds wintered at higher latitudes than birds in the other 2 groups. In addition to experiencing lower water temperatures, they also had fewer daylight hours available for food-searching and foraging. Resident birds spent dramatically less time floating on the water during the daytime than coastal and pelagic birds. The total time they spent flying and foraging during the day was equivalent to the time spent by birds in the other 2 categories, suggesting that they were expending an equivalent effort while spending less time resting during daylight hours. The fact that resident birds' flying bouts were longer on average than those of coastal birds may also indicate that prey was more difficult to find in the northern coastal region. Daytime foraging bouts were also longer for resident birds than for pelagic birds, possibly a sign of more intense foraging effort. Nightly resting times were not different among the 3 groups, implying that resident birds were not compensating for less rest during the day by resting more at night. In fact, residents spent more time in foraging activity at night than pelagic birds, possibly engaging in active body heat maintenance or actual nighttime foraging.

Many studies have suggested a link between seabird winter habitat conditions, survival (e.g. Sandvik et al. 2005, Frederiksen et al. 2008), and breeding biology (e.g. Chastel et al. 1995, Frederiksen et al. 2004). The proximate causes for such effects are often identifiable. For example, poor pre-breeding body condition may lead to delayed breeding or lowered reproductive success. Identifying the ultimate causes of such links, however, can prove difficult without a clear understanding of the conditions that seabirds endure during the non-breeding season. With the advent of miniaturized positioning sensors, collecting detailed data on winter distribution and activity patterns has become much more feasible, paving the way for comprehensive investigations into the ultimate relationships between overwintering conditions and seabird breeding biology (e.g. breeding condition, recruitment, survival, and breeding success).

Acknowledgements. We conducted this work with financial support from the Earthwatch Institute and the US Fish and Wildlife Service. We completed the data collection and analysis in collaboration with the British Antarctic Survey, with considerable assistance from J. Fox. In addition, R. Orben and an anonymous reviewer provided valuable feedback on this paper. Finally, we thank the many technicians and volunteers who helped to capture and resight birds, especially A. Robbins, K. Brenneman, T. Sandberg-Diment, G. Zager, J. Albanese, N. Nelson, J. O'Donnell, R. Sandberg-Diment, R. Pond, J. Stanley, and D. Cushing.

\section{LITERATURE CITED}

Ainley DG, Ford RG, Brown ED, Suryan RM, Irons DB (2003) Prey resources, competition, and geographic structure of kittiwake colonies in Prince William Sound. Ecology (USA) 84:709-723

Barbraud C, Chastel O (1999) Early body condition and hatching success in the snow petrel Pagodroma nivea. Polar Biol 21:1-4

Bogdanova MI, Daunt F, Newel M, Phillips RA, Harris MP, Wanless S (2011) Seasonal interactions in the blacklegged kittiwake, Rissa tridactyla: links between breeding performance and winter distribution. Proc R Soc Biol Sci B 278:2412-2418

Boyd IL, Murray AWA (2001) Monitoring a marine ecosys- 
tem using responses of upper trophic level predators. J Anim Ecol 70:747-760

- Burger J (1988) Foraging behavior in gulls: differences in method, prey, and habitat. Colon Waterbirds 11:9-23

Burtt EH (1974) Success of two feeding methods of the Black-legged Kittiwake. Auk 91:827-829

Cam E, Link WA, Cooch EG, Monnat JY, Danchin E (2002) Individual covariation in life-history traits: seeing the trees despite the forest. Am Nat 159:96-105

Chastel O, Weimerskirch H, Jouventin P (1995) Influence of body condition on reproductive decision and reproductive success in the blue petrel. Auk 112:964-972

$>$ Coulson JC (1966) The movements of the kittiwake. Bird Study 13:107-115

$>$ Daunt F, Benvenuti MP, Harris MP, Dall'Antonia L, Elston DA, Wanless S (2002) Foraging strategies of the blacklegged kittiwake Rissa tridactyla at a North Sea colony: evidence for a maximum foraging range. Mar Ecol Prog Ser 245:239-247

$>$ Daunt F, Afanasyev V, Silk JRD, Wanless S (2005) Extrinsic and intrinsic determinants of winter foraging and breeding phenology in a temperate seabird. Behav Ecol Sociobiol 59:381-388

De Solla SR, Bonduriansky R, Brooks RJ (1999) Eliminating autocorrelation reduces biological relevance of home range estimates. J Anim Ecol 68:221-234

Eichhorn G, Afanasyev V, Drent RH, van der Jeugd HP (2006) Spring stopover routines in Russian barnacle geese Branta leucopsis tracked by resightings and geolocation. Ardea 94:667-678

Feldman GC, McClain CR (2010) Ocean Color Web, Aqua MODIS Reprocessing Level 3 Mapped. NASA Goddard Space Flight Center. Kuring N, Bailey SW (eds). http:// oceancolor.gsfc.nasa.gov/

Frederiksen M, Harris MP, Daunt F, Rothey P, Wanless S (2004) Scale-dependent climate signals drive breeding phenology of three seabird species. Glob Change Biol 10:1214-1221

Frederiksen M, Daunt F, Harris MP, Wanless S (2008) The demographic impact of extreme events: stochastic weather drives survival and population dynamics in a long-lived seabird. J Anim Ecol 77:1020-1029

Furness RW, Nettleship DN (1991) Seabirds as monitors of changing marine environments. New Zealand Ornithological Congress Trust Board, Wellington

Gonzáles-Solís J, Croxall JP (2005) Differences in foraging behaviour and feeding ecology in giant petrels. In: Ruckstuhl KE, Neuhaus P (eds) Sexual segregation in vertebrates: ecology of the two sexes. Cambridge University Press, New York, NY, p 92-111

> Gonzáles-Solís J, Croxall JP, Oro D, Ruiz X (2007) Transequatorial migration and mixing in the wintering areas of a pelagic seabird. Front Ecol Environ 5:297-301

Gould PJ, Forsell DJ, Lensink CJ (1982) Pelagic distribution and abundance of seabirds in the Gulf of Alaska and the eastern Bering Sea, FWS/OBS-82/48. US Fish and Wildlife Service, Anchorage, AK

$>$ Harris MP, Daunt FF, Newell M, Phillips RA, Wanless S (2010) Wintering areas of adult Atlantic puffins Fratercula arctica from a North Sea colony as revealed by geolocation technology. Mar Biol 157:827-836

Henson SA, Thomas AC (2008) A census of oceanic anticyclonic eddies in the Gulf of Alaska. Deep-Sea Res I 55: 163-176

Hill RD (1994) Theory of geolocation by light levels. In:
LeBoeuf BJ, Laws RM (eds) Elephant seals: population ecology, behaviour, and physiology. University of California Press, Berkeley, CA, p 227-236

Humphreys EM, Wanless S, Bryant DM (2007) Elevated metabolic costs while resting on water in a surface feeder: the Black-legged Kittiwake Rissa tridactyla. Ibis 149:106-111

Irons DB (1998) Foraging area fidelity of individual seabirds in relation to tidal cycles and flock feeding. Ecology 79 : 647-655

Jodice PGR, Lanctot RB, Gill VA, Roby DD, Hatch SA (2000) Sexing adult black-legged kittiwakes by DNA, behavior, and morphology. Waterbirds 23:405-415

- Kappes MA, Shaffer SA, Tremblay Y, Foley DG and others (2010) Hawaiian albatrosses track interannual variability of marine habitats in the North Pacific. Prog Oceanogr 86:246-260

Kinder TH, Hunt GL, Schneider D, Schumacher JD (1983) Correlations between seabirds and oceanic fronts around the Pribilof Islands, Alaska. Estuar Coast Shelf Sci 16:309-319

> Lee T, McPhaden MJ (2010) Increasing intensity of El Niño in the central-equatorial Pacific. Geophys Res Lett 37, L14603, doi:10.1029/2010GL044007

Massaro M, Chardine JW, Jones IL, Robertson GJ (2000) Delayed capelin (Mallotus cillosus) availability influences predator behaviour of large gulls on black-legged kittiwakes (Rissa tridactyla), causing a reduction in kittiwake breeding success. Can J Zool 78:1588-1596

McKnight AE, Sullivan KM, Irons DB, Howlin S (2008) Marine bird and sea otter population abundance of Prince William Sound, Alaska: trends following the $T / V$ Exxon Valdez oil spill, 1989-2007, restoration project no. 070751. Exxon Valdez oil spill restoration project annual report. US Fish and Wildlife Service, Anchorage, AK

Montevecchi WA (1993) Birds as indicators of change in marine prey stocks. In: Furness RW, Greenwood JD (eds) Birds as monitors of environmental change. Chapman \& Hall, London, p 217-266

O'Hara PD, Morgan KH, Sydeman WJ (2006) Primary producer and seabird associations with AVHRR-derived sea surface temperatures and gradients in the southeastern Gulf of Alaska. Deep-Sea Res II 53:359-369

Phillips RA, Silk JRD, Croxall JP, Afanasyev V, Briggs DR (2004) Accuracy of geolocation estimates for flying seabirds. Mar Ecol Prog Ser 266:265-272

Phillips RA, Silk JRD, Croxall JP (2005) Foraging and provisioning strategies of the light-mantled sooty albatross at South Georgia: competition and co-existence with sympatric pelagic predators. Mar Ecol Prog Ser 285:259-270

Phillips RA, Silk JRD, Croxall JP, Afanasyev V (2006) Yearround distribution of white-chinned petrels from South Georgia: relationships with oceanography and fisheries. Biol Conserv 129:336-347

- Polovina JJ, Howell E, Kobayashi DR, Seki MP (2001) The transition zone chlorophyll front, a dynamic global feature defining migration and forage habitat for marine resources. Prog Oceanogr 49:469-483

Rankin MN, Duffey EAG (1948) A study of the bird life of the North Atlantic. Br Birds 41(Suppl):1-42

Sandvik H, Erikstad KE, Barrett RT, Yoccoz NG (2005) The effect of climate on adult survival in five species of North Atlantic seabirds. J Anim Ecol 74:817-831

Schneider D (1982) Fronts and seabird aggregations in the southeastern Bering Sea. Mar Ecol Prog Ser 10:101-103 
Shaffer SA, Tremblay Y, Awkerman JA, Henry RW and others (2005) Comparison of light- and SST-based geolocation with satellite telemetry in free-ranging albatrosses. Mar Biol 147:833-843

Spear LB, Ainley DG (1997) Flight speed of seabirds in relation to wind speed and direction. Ibis 139:234-251

Stutchbury BJM, Tarof SA, Done T, Gow E and others (2009) Tracking long-distance songbird migration by using geolocators. Science 323:896

Weimerskirch H, Le Corre M, Jaquemet S, Potier M, Marsac F (2004) Foraging strategy of a top predator in tropical waters: great frigatebirds in the Mozambique Channel.

Editorial responsibility: Rory Wilson,

Swansea, UK
Mar Ecol Prog Ser 275:297-308

Whitney FA, Welch DW (2002) Impact of the 1997-1998 El Niño and 1999 La Niña on nutrient supply in the Gulf of Alaska. Prog Oceanogr 54:405-421

Wilson RP, Ducamp JJ, Reese WG, Culik BM, Niekamp K (1992) Estimation of location: global coverage using light intensity. In: Priede IG, Swift SM (eds) Wildlife telemetry: remote monitoring and tracking of animals. Ellis Horwood, New York, NY, p 131-134

Wynne-Edwards VC (1935) On the habits and distribution of birds on the North Atlantic. Proc Boston Soc Nat Hist 40: 233-346

Submitted: June 8, 2011; Accepted: August 29, 2011 Proofs received from author(s): November 21, 2011 